\title{
The Impact of Organizational Behavior on Organizational Citizenship Behavior A Field study on BEMO Saudi Fransi Bank
}

\author{
Bashar Haj Ali \\ Higher institute for Business Administration, Damascus - Syria \\ E-mail: Bachar.hajali85@gmail.com
}

Received: Feb. 26, 2020 Accepted: Mar. 20, 2020 Online published: Mar. 30, 2020

doi:10.5296/ijhrs.v10i2.16776 URL: https://doi.org/10.5296/ijhrs.v10i2.16776

\begin{abstract}
The aim of this research is to study the three dimensions of organizational behavior (evaluation of the worker's personality, the motives of the worker, its interactivity within the work team) and the dimensions of organizational citizenship (altruism, general compliance, conscience awareness and civilizational behavior) among Bemo Saudi Fransi employees. (163) questionnaires were distributed to those who accepted to participate in the study and based on the approval and direction of the relevant departments in Bemo Saudi Fransi Bank, where the number of the sample's employees is (690) employees, and it was concluded that there was a statistically significant effect of the organizational behavior variables (evaluation of the worker's personality, The motivations of the worker) while there is no relation to the variable (interactivity within the work team) in the behavior of organizational citizenship towards the management of the bank (altruism) and the presence of a statistically significant effect of organizational behavior variables (evaluation of the worker's personality, worker motivations, the ability of the worker to interact within the work team) in the behavior of Organizational citizenship towards bank management (A. Compliance with the public, awareness of conscience and civilized behavior). It was also found that there are fundamental differences attributable to the gender variable of the sample, as the males volunteer to carry out the tasks that are not required of them except that they take breaks that they do not deserve and do not spend their time working without making an effort, while the females help others who were absent from their work and seek accuracy in their work times while the absence of fundamental differences Regarding the variables of organizational behavior and organizational citizenship in relation to the variable of the academic level of the sample. It was recommended that employees should be involved more in the management of a bank by setting up awareness sessions for them and doing some administrative matters within the
\end{abstract}


management of a bank and opening means and channels of communication with management continuously and periodically, and trying to support the sense of creativity and innovation for workers in Bemo Saudi Fransi Bank and to conduct training courses and that By training employees to improve the image of a bank's management and to perform the job with perfection and dedication.

Keywords: organizational behavior, organizational citizenship behavior, team work environment, evaluation

\section{Introduction}

Organizational behavior has received a lot of attention from researchers in human resources management in its various specializations, as researchers focus on the role of organizational behavior in the work environment. They clarified that awareness of employees in organizational behavior greatly affects many organizational goals, including employee attitudes toward the company and between them and others, which include job satisfaction, intent to leave, organizational commitment, and behavior at work.

Hence this study came to highlight the employees 'perception of organizational behavior and the perception of organizational citizenship for employees of Bemo Saudi Fransi Bank. The descriptive analytical approach will be followed through collecting quantitative data and subjecting it to appropriate statistical analyzes to answer the research hypotheses. The study community has been chosen banks due to the ability to access the sample within the bank, taking into account the various departments it contains and its important and vital role in providing various services and dealing with many segments of customers, especially during the crisis in the Syrian Arab Republic, and despite the The abundance of different studies and research in the field of organizational behavior and organizational citizenship as independent variables, but studies in the field of their relationship are still limited, especially in the banking and administrative sector.

\section{Previous Studies}

Some studies dealt with the concept of organizational behavior and its relationship to the awareness of organizational citizenship, so the researcher had to stop at some of these studies, choose what serves the research topic, and review the most important results, and then show what distinguishes this study from them, and from previous studies that were relied upon where AlA'wasa, S., 2018. The Impact of Organizational Justice on the Counterproductive Work Behavior. International Journal of Business and Social Science, Jordan aimed to find the effect of organizational behavior on the realization of effective citizenship by examining both the employee's personality and his motives on the altruism variable and conscience awareness within a government service center in Jordan, by distributing a questionnaire to 340 employees, where it was found that there was a statistically significant effect of a variable Personality of the worker on selflessness and awareness of the conscience, as there was a significant effect of the motives of the worker on altruism, while there was no effect of the variable of motivations of work on awareness of the conscience.

And Ajlouni, W., Kaur, G., Faisal, A. \& AlGharaibeh, S., 2018. entitled Organizational Justise 
and It's relatioship with organizational Classinship behavior of nonacademic staff members at Goverment Universities in north of Jordan. Academy of Strategic Management Journal, 17 (6).

This study worked to understand what is related to the existence of an effect of the worker's personality variable on altruism. The questionnaire was distributed to 210 non-academic employees within universities located in northern Jordan, and it was found that there was no such effect among non-academic employees in universities in Jordan, while an effect was found for each of Variable inclinations and values of the factor on altruism, general compliance, and conscience awareness.

And LawrenceChuku, E. \& Needorn, R., 2018. Organizational Justice and Workers' Citizenship Behavior. International Journal of Advanced Academic Research, Nigeria, 4 (5),

The study aimed to show the effect of organizational behavior variables represented in the ability to interact and the possibility of compatibility between his professional and family life in addition to the personality of the worker on the variables of awareness of organizational citizenship in the consciousness of conscience and cultural behavior and altruism in Nigeria, where a questionnaire was distributed to 169 hotel employees in the Harcourt port The effect of organizational behavior variables on organizational citizenship awareness represented by conscience awareness, civilizational behavior and altruism in Nigeria was demonstrated.

Then Waqas Umer Malik Study, 2018. Entitled: Influence of Transformational Leadership Components on Job Satisfaction and Organizational Citizenship behavior.

This study aimed to find out the effect of the components related to organizational behavior on job satisfaction and organizational citizenship. The questionnaires were distributed to 5 Islamic banks in Pakistan from Gujranwala section which includes 56 branches. It was distributed to 319 employees from 25 branches, information was collected through a structured questionnaire containing 26 items, and a five-Likert scale was used.

The study revealed an effect of the components of organizational behavior on job satisfaction and organizational citizenship. But it still lacks the application of regulatory citizenship and its components in Islamic banks in Pakistan. Moreover there is a huge communication gap as most managers did not have awareness of this.

\section{Study Problem}

Several previous studies have talked about the employee's awareness of organizational behavior is one of the main criteria in determining his inclinations towards the management of a bank in which he works, where organizational behavior focuses on the employees 'awareness of what they offer to the organization and the benefits they receive, and therefore the imbalance in this awareness (such as feeling injustice And other feelings) may be reflected negatively on the level of organizational citizenship of workers in the management of a bank.

Thus, the study problem revolves around the following questions: 


\section{Macrothink}

International Journal of Human Resource Studies

ISSN 2162-3058

2020, Vol. 10, No. 2

1- What is the level of organizational behavior in its various dimensions among employees of Bemo Saudi Fransi Bank?

2- What is the level of organizational citizenship for employees of Bemo Saudi Fransi for organizational citizenship?

3- What is the effect of organizational behavior in its three dimensions (assessing the employee's personality, worker's motivations, interactivity within the work team) on organizational citizenship towards the bank with its dimensions (altruism, general compliance, conscience awareness and civilizational behavior) among employees of Bemo Saudi Fransi Bank?

\section{Study Importance}

The importance of this study is highlighted in its modern topic, which has become the focus of concerns of modern organizations. In addition to the lack of studies that dealt with the subject of the study, this study can add a new vision on the importance of awareness of organizational citizenship, and it could be a starting point for more studies and research on organizational behavior and awareness of organizational citizenship, and the researcher hopes that this study will add an increase in his knowledge and enrich his information In this field and to classify this study as a new addition to the Syrian and Arab library.

And in practical way The importance of the study stems from the need to understand the reality of the practice of perceiving organizational citizenship in light of the availability of organizational behavior among the employees of Bemo Saudi Fransi Bank. It is also the first study of its kind in Bemo Saudi Fransi Bank.

This will help bank administrators understand the differences and behaviors in managing a bank in order to improve it and avoid its consequences in the future.

\section{Study Objective}

The study seeks to reveal the relationship between the three dimensions of organizational behavior (evaluation of the employee's personality, worker motivations, interactivity within the work team) and the dimensions of organizational citizenship (altruism, general compliance, conscience awareness and civilizational behavior) among Bemo Saudi Fransi employees.

\section{Study Method and Procedures}

\subsection{Study Variables}

The independent variable: organizational behavior and consists of four dimensions, namely:

- Personality of the worker

- The worker's motives

- The ability of workers to interact within the team

Which was based on the Likert pentatonic scale through the questionnaire consisting of 13 questions. 


\section{Macrothink}

The Dependent variable: organizational citizenship

Which was based on the Likert pentatonic scale through the questionnaire, which consisted of 20 questions.

Organizational citizenship was divided into:

- Altruism

- General compliance

- Conscience Awareness

- Civilized behavior

\subsection{Study Sample}

This study targets workers in Bemo Saudi Fransi Bank, which is considered one of the largest traditional private banks operating in the Syrian Arab Republic, and (163) questionnaires were distributed to those who accepted to participate in the study and based on the approval and guidance of the relevant departments in Bemo Saudi Fransi Bank, where the number The sample employees (690) employees.

\subsection{Study Tool}

A questionnaire was used based on measures developed by other researchers for each individual dimension in order to test the study questions. The questionnaire was divided into two parts:

The first section, which consists of demographic and functional questions.

\section{Section Two:}

The first axis is organizational behavior, and it consists of the following dimensions:

1. The first dimension assesses the personality of the worker and consists of 6 questions. Where the questions were adopted from the scale (Akram, et al., 2016).

2. The second dimension of the worker's motives and consists of 3 questions. Where the questions were adopted from the scale (Özer, et al., 2017).

3. The third dimension is the employability of workers within the team and consists of 4 questions. Where questions were adopted from the scale (Qureshi, et al., 2016)

The second axis is awareness of organizational citizenship, and it consists of the following dimensions:

4. The first dimension of altruism consists of 5 questions. Where the questions were adopted from the scale (Ismail, et al., 2018)

5. The second dimension is general compliance and consists of 5 questions. Where questions were adopted from the scale (Majeed, et al., 2018)

6. The third dimension is conscience awareness and consists of 5 questions. Where questions were adopted from the scale (Podsakoff, et al., 1990)

7. The fourth dimension of civilized behavior and consists of 5 questions. Where questions were adopted from the scale (Podsakoff, et al., 2000) 
The Likert pentaton scale was used to classify the sample responses as follows:

5 Strongly Agree, 4 Agree, 3 Neutral, 2 Disagree, 1 Strongly Disagree.

\section{Study Hypotheses}

Depending on the above, the following assumptions will be adopted:

H1 The first main hypothesis: There is a high level of organizational behavior among workers in organizational citizenship in Bemo Saudi Fransi Bank. It divides the following hypotheses:

H1.1: There is no statistically significant effect of the three dimensions of organizational behavior (assessment of worker personality, worker motivations, interactivity within a team) and after altruism of the dimensions of organizational citizenship.

H1.2: There is no statistically significant effect of the three dimensions of organizational behavior (assessment of worker personality, worker motivations, interactivity within a team) and after general compliance with the dimensions of organizational citizenship.

H1.3: There is no statistically significant effect of the three dimensions of organizational behavior (assessment of the worker's personality, worker's motivations, interactivity within the team) and after conscience awareness of the dimensions of organizational citizenship.

H1.4: There is no statistically significant effect of the three dimensions of organizational behavior (assessment of worker personality, worker motivations, interactivity within the work team) and after civilized behavior from the dimensions of organizational citizenship.

$\mathrm{H} 2$ : The second main hypothesis: There are no fundamental differences with regard to the awareness of organizational citizenship with regard to demographic variables of the sample in Bemo Saudi Fransi Bank. It divides the following hypotheses:

$\mathrm{H} 2.1$ : There are no significant differences in the perception of organizational citizenship with regard to the gender variable of the sample.

H2.2: There are no significant differences in the perception of organizational citizenship with regard to the variable academic level of the sample.

\section{Theoretical Framework for the Research}

\subsection{Organizational Behavior}

We need an explanation of the behavior of the people with whom we work, and the research and the suffering that we encounter may lengthen in trying to understand others and even in understanding ourselves, we may need to know the reasons leading to the behavior, and also the reason to continue this behavior or switch from it, and if we move to The field of business and the organizations in which we work, the greater the need for superiors, colleagues, and subordinates to understand each other, because this understanding greatly affects the economic outcomes of work.

Organizational behavior: a field of knowledge interested in studying the impact of individuals, groups, and organizational structure on behavior within organizations for the purpose of 
applying this knowledge to improve the interactivity of bank management.

And Greenberg \& Baron defined organizational behavior as (an area interested in knowing all aspects of human behavior in organizations, through the systematic study of the individual, group, and organizational processes, and that the primary goal of this knowledge is to increase organizational effectiveness and increase the well-being of the individual.

\subsection{Concept and Definition of Organizational Citizenship Behavior}

In-depth studies of organizational citizenship behavior have begun within the broader understanding of social exchange theory.This concept can be viewed from a two-way perspective related to the types of volunteer practices aimed at achieving organizational dimension, while the other relates to the desire to help colleagues perform their roles and duties to achieve better Balance between personal and organizational dimensions, where organizational citizenship behavior reflects advanced levels of professionalism and immersion in work, and the professional and ethical maturity of leading systems and their employees to frame their practices with a highly ethical system. Selflessness, heterosexuality, belonging, conscientiousness, active participation and initiative to develop organizational practices, provide additional voluntary efforts away from formal control and external control.

The concept of organizational citizenship is one of the administrative concepts recently produced by modern administrative thought and has attracted the interest of researchers and practitioners alike. The focus of the concept is on the factor that is one of the most important organizational resources at all. It is a basic pillar of development and progress in any society, as it is known that most developed countries have reached their prosperity and development in various fields because of the attention they have placed on their human resource.

Over the past decade, there has been increased interest in the concept of organizational citizenship behavior, which is not specific and is not officially linked to the incentive and performance appraisal systems of organizations, which is important for all organizations as organizations that rely solely on formal behavior are fragile and fragile systems, and organizations must leave part Of indeterminate behavior of individuals so they have the ability to deal with unexpected situations that require innovation behave by individuals.

Bernard's writings in 1938 on the real desires of individuals and their willingness to provide good services and actions are the beginning of the real spark in analyzing the driving foundations of organizational behavior, which Katz later relied upon in 1964, when he identified three main types of driving foundations for organizational behavior (1964 Katz,). At the end of the 1970s, the term Organizational Citizenship Behavior (OCB) was introduced by Organ in 1977, describing automatic collaborative and innovative behaviors when he studied the relationships between job satisfaction and performance, and then a study (Organ, 1977). It has shown that although there is no strong relationship between job satisfaction and productivity, job satisfaction is strongly associated with organizational citizenship behaviors because the latter is less restrictive and dependent on both the individual's ability and the technology employed at work compared to productivity. Since 1983, research and studies have continued. That dealt with organizational citizenship behaviors both in theory and in 
practice.

\section{Study Methodology}

Reliance was placed on philosophy that adopts the deductive approach as the method of study, that is, thinking will be focused on starting from the general to the private, i.e. converting the theory that talks about the relationship between organizational behavior and organizational citizenship to specific hypotheses that can be tested, in addition to relying on the quantitative approach in research using The questionnaire is distributed in the field to the study sample, and in this framework, the literature on the topic of the research was seen at the beginning in order to define the concepts of organizational behavior and organizational citizenship to be studied, and then a questionnaire will be designed to collect and recommend In the data of the research sample, the analysis of that data, and the testing of hypotheses of the research using appropriate statistical methods and programs for this purpose, this study will rely on two main sources to obtain the data, namely:

- Primary sources: where the questionnaire will be relied upon to measure independent and dependent variables, and it will be distributed to the sample items.

- Secondary sources: relying on books and studies related to the subject through libraries and previous studies.

\section{Statistical Analysis Methods}

Descriptive statistics will be used in this study, through studying standard averages and deviations, in addition to the independence sample $\mathrm{T}$ test and simple and multiple linear regression analysis.

\subsection{Statistical Analysis of Study Data and Results}

Where it is observed that the quality of the sample is distributed according to gender, where it is observed that $75.5 \%$ of the employees are females while $24.5 \%$ of the employees are male, while for the study it was observed that $68.7 \%$ of them have university degrees, $23.3 \%$ of them are graduates and $8 \%$ of Holders of secondary education certificates and less, and this indicates that the major majority of the employees of Bemo Saudi Fransi Bank hold degrees.

The sample was also distributed according to age, where it is noted that the majority of employees are between 18-25 years, as the sample was divided between 58\% between 18-25 years for employees. As for ages between 26-32 years, the proportion of employees was about $24 \%$, while for employees it is about $9 \%$ of the sample are above 32 years old.

\subsection{Hypotheses Test}

\section{The first hypothesis:}

1- What is the effect of Bemo Saudi Fransi's awareness of organizational behavior (evaluation of the employee's personality, worker's motives, the worker's interactivity within the work team) in organizational citizenship towards the management of the (altruism) bank?

To test the first sub-hypothesis, a linear regression coefficient test was used, which says what 
is the effect of awareness of the three dimensions of organizational behavior (evaluation of the employee's personality, worker's motives, interactivity within the work team) in the altruism dimension towards the management of a bank where the value of sig $=0,000$ which is less than 0.05 and according to the curricula, practical research shows The presence of a significant effect of organizational behavior on the distance of altruism in organizational citizenship, as the value of the correlation coefficient $=78.4 \%$, which is positive, that is, there is a direct relationship between the variables and the value of the determination factor $61.5 \%$, that is, the relationship strength is strong, as was the value of the modified determination factor $60.8 \%$, i.e. $60.8 \%$ of the variables that influence after altruism $\mathrm{J}$ of organizational behavior variables.

From this it is possible to calculate the linear regression equation, which appears as follows:

$\mathrm{Y}=0.926+0.426 \mathrm{X} 1+0.377 \mathrm{X} 2$

Whereas, X1: evaluation of the worker's personality, X2: the motivation of the worker,

From it, each increase by $42.6 \%$ of the employee's personality assessment and $37.7 \%$ of the worker's motivations increases the employee preference, which is considered a dimension of citizenship behaviors.

This effect can be demonstrated through the work of Bemo Saudi Fransi Bank to establish the concept of organizational behavior among employees, which helps in the citizenship behaviors they own, and that the increase in personal relations between employees and management has led to a decrease in the altruism variable among employees.

2- There is no statistically significant effect of the three dimensions of organizational behavior (evaluation of the employee's personality, worker's motivations, interactivity within the team) and organizational citizenship dimensions (general compliance).

To test the second sub-hypothesis, a linear regression coefficient test was used which says what effect did Bemo Banque Saudi Fransi perceive organizational behavior (assessment of the employee's personality, employee's motives, the worker's interactivity within the work team) in the general compliance dimension. Where the value of sig $=0.000$, which is less than 0.05 , and according to the practical research methodology, there was a significant effect of organizational behavior on the general compliance dimension in organizational citizenship, and the value of correlation coefficient $=79 \%$, which is positive, meaning that there is a direct relationship between the variables and the value of a coefficient. Determination $62.4 \%$, i.e. the strength of the relationship is strong, as was the value of the adjusted coefficient of determination, $61.7 \%$, meaning that $61.7 \%$ of the variables that affect the general compliance dimension are among the variables of organizational behavior.

From this it is possible to calculate the linear regression equation, which appears as follows:

$\mathrm{Y}=0.958+0.467 \mathrm{X} 1-0.249 \mathrm{X} 2+0.480 \mathrm{X} 3$

Whereas, X1: evaluation of the personality of the worker, X2: the motivations of the worker, X3: the susceptibility of the worker to interaction within the team 
From it, each increase by $46.7 \%$ from the evaluation of the worker's personality and $48 \%$ from the worker's interactivity within the work team, and every decrease by $24.9 \%$ of the worker's motives increases the general compliance of employees and workers alike, which are considered to be dimensions of citizenship behaviors. It can be clarified that exaggeration of the process of worker motivation among employees led to a decrease in general compliance, given that there are many motives in which the worker works in the bank, regardless of his love for his work or the bank itself.

3- There is no statistically significant effect of the three dimensions of organizational behavior (assessment of the worker's personality, worker's motives, interactivity within the team) and organizational citizenship dimensions (conscience awareness).

To test the third sub-hypothesis, a linear regression coefficient test was used, which says what is the effect of the awareness of Bemo Saudi Fransi employees on the organizational behavior (assessment of the employee's personality, the worker's motives, the employability of the worker within the work team) in the dimension of conscience. Where the value of sig $=0.000$, which is less than 0.05 and according to the practical research methodology, there was a significant effect of organizational behavior on the conscience consciousness dimension in organizational citizenship, and the value of correlation coefficient $=68 \%$, which is positive, that is, there is a direct relationship between the variables and the value of a coefficient. Determination $46.3 \%$, i.e. the strength of the relationship is strong, as was the value of the adjusted coefficient of identification $45.2 \%$, meaning that $45.2 \%$ of the variables that affect the dimension of consciousness of conscience are variables of organizational behavior.

From this it is possible to calculate the linear regression equation, which appears as follows:

$\mathrm{Y}=1.239+0.562 \mathrm{X} 1-0.239 \mathrm{X} 2+0.347 \mathrm{X} 3$

Whereas, X1: evaluation of the personality of the worker, X2: the motivations of the worker, X3: the susceptibility of the worker to interaction within the team

From it, each increase by $56.2 \%$ from the evaluation of the worker's personality and $34.7 \%$ from the worker's ability to interact within the work team, and every decrease by $23.9 \%$ from the worker's motives increases the awareness of the employee conscience, which is considered a dimension of citizenship behaviors.

It can be explained that the exaggeration of the workability of the worker within the work team and the lack of some respect between the employees led to a decrease in conscience awareness due to their conviction not to be held accountable because of the friendly relations between each other.

4- There is no statistically significant effect of the three dimensions of organizational behavior (evaluation of the worker's personality, worker's motivations, interactivity within the team) and organizational citizenship dimensions (civilized behavior).

To test the fourth sub-hypothesis, a linear regression coefficient test was used, where the value of sig $=0.159$ which is greater than 0.05 and according to the methods of practical research shows that there was no significant effect of organizational behavior on the 
dimension of civilized behavior in organizational citizenship.

The second hypothesis:

1- There are no significant differences in the perception of organizational citizenship regarding the gender variable of the sample.

For the first sub-hypothesis test, an independence sample $\mathrm{T}$ test was used, Where it is noted from the previous tables that there are no fundamental differences in relation to the variables of organizational behavior and organizational citizenship with regard to the gender variable of the sample, considering that the value of SIG is greater than 0.05 except in the altruism variable where it is noted that the value of SIG was smaller than 0.05 and this is evidence of the existence of fundamental differences due to a variable Gender for the sample, where it is noticed that the average value of male answers to the questions of altruism is 3.3 which is slightly greater than the average of female answers, where it can be explained that males volunteer to carry out tasks that are not required of them except that they take breaks that they do not deserve and do not spend their time working without making an effort while Female helps The other people who are absent from their work and be precise in their working hours, and this is due to the different nature of both males and females.

2- There are no significant differences regarding the awareness of organizational citizenship regarding the variable of the academic level of the sample.

For the second sub-hypothesis, an independence sample $\mathrm{T}$ test was used Where it is noted from the previous tables that there are no fundamental differences with respect to the variables of organizational behavior and organizational citizenship with regard to the variable of the academic level of the sample.

\section{Results}

The following was concluded:

1-There is a statistically significant effect of organizational behavior variables (evaluation of the employee's personality, worker's motives) while there is no relative (interactivity within the work team) variable in the altruism of the dimensions of organizational citizenship towards a bank's management, and this is similar to the majority of previous studies such as the (broader) study 2018) and the study (Al-Ajlouni, 2018) and the study (Lawrence, 2018), and there is also a statistically significant effect of organizational behavior variables (assessment of worker personality, worker motivations, worker interactivity within the work team) in the general. compliance dimension of organizational citizenship dimensions towards management bank. This is similar to a study (Lawrence, 2018).

2-The confirmation of the concept of organizational behavior among employees, which helps in the citizenship behaviors they possess, and that the increase in personal relations between employees and management has led to a decrease in the altruism variable among employees

3- There is a statistically significant effect of organizational behavior variables (evaluation of the employee's personality, worker's motives, the worker's interactivity within the work team) 
in the conscience awareness of the dimensions of organizational citizenship toward bank management. This is similar to the majority of previous studies such as the study (Al-Ajlouni, 2018) and the study (Lawrence, 2018), and it conflicts with the study (the broader, 2018), and there is no statistically significant effect for the three dimensions of organizational behavior (assessment of the worker's personality, worker motivations, interactivity within The work team) on the dimension of civilized behavior from the dimensions of organizational citizenship towards the management of a bank, and this conflicts with the study (Lawrence, 2018)

4-The exaggeration of the process of worker motivation among employees led to a decrease in general compliance due to the presence of many motives in which the worker works in the bank, regardless of his love for his work or the bank itself.

5-The exaggeration of the workability of the worker within the work team and the lack of some respect between the employees led to a decrease in conscience awareness due to their conviction not to be held accountable because of the friendly relations between each other.

6-There are fundamental differences attributable to the gender variable of the sample, as males volunteer to carry out tasks that are not required of them, except that they take breaks that they do not deserve and do not spend their time working without making an effort, while females help others who are absent from their work and are careful in their work schedules.

7-There are no fundamental differences with respect to the variables of organizational behavior and organizational citizenship with regard to the variable of the academic level of the sample, there is no sense of creativity and innovation for employees in Bemo Saudi Fransi Bank, and the employees are not interested in improving the image of bank management or performing the work with perfection and dedication.

8- Males volunteer to do the tasks that are not required of them, except that they take breaks that they do not deserve and do not spend their time working without making an effort, while females help others who are absent from their work and seek accuracy in their work hours, and this is due to the different nature of both males and females.

\section{Recommendations}

Based on the previous results, the following recommendations were reached:

1. Working to involve employees more in managing a bank by setting up awareness sessions for them and doing some administrative matters within the management of a bank, in addition to establishing and developing the concept of organizational citizenship for workers in particular in order to improve work and contribute to improving the performance of this bank management through reward Workers with voluntary behavior, holding honoring parties for them, and considering citizenship behavior as one of the criteria for meeting the performance of employees and workers.

2. Attempting to pay some of the incentives for employees to increase the degree of organizational loyalty, including the direction of Bemo Saudi Fransi Bank, and give the workers the ability to challenge the results issued by the administration in order to increase 
the degree of loyalty to the organization, and to open the means and channels of communication with management continuously and periodically, and try to support the sense of creativity And innovation for employees of Bemo Saudi Fransi Bank, in addition to conducting training courses by training workers to improve the image of bank management and performing the work with perfection and dedication.

\section{References}

Ajlouni, W. M. E., Kaur, G., \& Al-Gharaibeh, S. (2018). Organizational Justice and its Relationship with Organizational Citizenship Behavior of Non-Academic Staff Members at Government Universities in North of Jordan. Academy of Strategic Management Journal.

Al-A'wasa, S. I. S. (2018). The Impact of Organizational Justice on the Counterproductive Work Behavior (CWB): A Field Study Conducted in the Jordan Customs Department (JCD). International Journal of Business and Social Science, 9(1), 27-38.

Amsa, P., \& Aithal, K. N. (1989). Effectiveness and Leadership Behaviour of Regional Managers in a Public Sector Bank-an Empirical Study. Decision, 16(2), 137.

Amsa, P., \& Aithal, K. N. (1989). Effectiveness and Leadership Behaviour of Regional Managers in a Public Sector Bank-an Empirical Study. Decision, 16(2), 137.

Andrieș, A. M. (2011). Positive and negative emotions within the organizational context. Global journal of human social science, 11(9), 27-39.

Bahl, A. (2010). Managerial Effectiveness: A Vedanta in Management. Abhigyan.

Bogler, R., \& Somech, A. (2005). Organizational citizenship behavior in school. Journal of educational Administration. https://doi.org/10.1108/09578230510615215

Campbell et al. (2016). Managerial Behaviour Performance and Effectiveness. M.C. Graw Hill: New York.

Campo, M., Champely, S., Lane, A. M., Rosnet, E., Ferrand, C., \& Louvet., B. (2016). Emotions and performance in rugby. Journal of Sport and Health Science, 1(10).

Chauhan, V. S., Dhar, U., \& Pathak, R. D. (2005). Factorial constitution of managerial effectiveness. Journal of Managerial Psychology.

Cho, S., \& Johanson, M. M. (2008). Organizational citizenship behavior and employee performance: A moderating effect of work status in restaurant employees. Journal of Hospitality \& Tourism Research, 32(3), 307-326. https://doi.org/10.1177/1096348008317390

Colin, H. (2006). Managing through organisations: The management process. Forms of Organisation and the work of Managers, Routledge London.

Daniels, D., Joireman, J., Falvy, J., \& Kamdar, D. (2006). Organizational citizenship behavior as function of empathy consideration of future consequences, and employee time horizon: an initial exploration using an inbasket simulation of OCBs. Journal of Applied Social Psychology, 36(9), 2266-2292. https://doi.org/10.1111/j.0021-9029.2006.00103.x 
Døjbak Håkonsson, D., Eskildsen, J. K., Argote, L., Mønster, D., Burton, R. M., \& Obel, B. (2016). Exploration versus exploitation: Emotions and performance as antecedents and consequences of team decisions. Strategic Management Journal, 37(6), 985-1001. https://doi.org/10.1002/smj.2380

Elfenbein, H. A., Polzer, J. T., \& Ambady, N. (2007). Chapter 4 Team Emotion Recognition Accuracy and Team Performance. Research on emotion in organizations, 3, 87-119. https://doi.org/10.1016/S1746-9791(07)03004-0

Folger, R., \& Konovsky, M. A. (1989). Effects of procedural and distributive justice on reactions to pay raise decisions. Academy of Management journal, 32(1), 115-130. https://doi.org/10.2307/256422

Ganesh, M. P., \& Gupta, M. (2010). Impact of virtualness and task interdependence on extra-role performance in software development teams. Team Performance Management: An International Journal. https://doi.org/10.1108/13527591011053250

Gangopadhyay, A. (2016). Importance of work culture, work culture in public service institutions, Himalaya Publishing House.

Gardner, W. L., Fischer, D., \& Hunt, J. G. J. (2009). Emotional labor and leadership: A threat to authenticity? The Leadership Quarterly, 20(3), 466-482. https://doi.org/10.1016/j.leaqua.2009.03.011

Hagger, M. S., Wood, C., Stiff, C., \& Chatzisarantis, N. L. (2010). Ego depletion and the strength model of self-control: a meta-analysis. Psychological bulletin, 136(4), 495. https://doi.org/10.1037/a0019486

Halbesleben, J., \& Bellairs, T. (2016). What Are the Motives for Employees to Exhibit Citizenship Behavior.

Klauss, R. (1977). Measuring the Impact on Subordinates of Manager's Interpersonal Communication Styles and Credibility Affairs, Defense Technical Information Centre.

Krishnan, V. R., \& Arora, P. (2008). Determinants of transformational leadership and organizational citizenship behavior. Asia Pacific Business Review, 4(1), 34-43. https://doi.org/10.1177/097324700800400104

Kwantes, C. T., \& Boglarsky, C. A. (2007). Perceptions of organizational culture, leadership effectiveness and personal effectiveness across six countries. Journal of International management, 13(2), 204-230. https://doi.org/10.1016/j.intman.2007.03.002

Lawrence, C. E., \& Needorn, R. (2018). Organizational Justice and Workers' Citizenship Behaviour. International Journal of Advanced Academic Research Nigeria, 4(5), 103-129.

Luthans, F. (1992). Organisational behaviour 6th ed.

Maranges, H. M., Schmeichel, B. J., \& Baumeister, R. F. (2017). Comparing cognitive load and self-regulatory depletion: Effects on emotions and cognitions. Learning and Instruction, 51, 74-84. https://doi.org/10.1016/j.learninstruc.2016.10.010 


\section{Ml Macrothink}

International Journal of Human Resource Studies ISSN 2162-3058 2020, Vol. 10, No. 2

Miao, R. T., \& Kim, H. G. (2009, November). The impact of organizational citizenship behavior on team effectiveness in China: The moderating role of task complexity. In 2009 Fourth International Conference on Computer Sciences and Convergence Information Technology (pp. 641-646). IEEE. https://doi.org/10.1109/ICCIT.2009.200

Pan, X., Chen, M., Hao, Z., \& Bi, W. (2018). The effects of organizational justice on positive organizational behavior: Evidence from a large-sample survey and a situational experiment. Frontiers in psychology, 8, 2315. https://doi.org/10.3389/fpsyg.2017.02315

Rishipal, M. (2013). Performance management and employee loyalty. Global Journal of Management And Business Research.

Robbins, S. P. (2016). Organizational Behavior: Concepts controversies, and applications (11th Ed). New Delhi. Prentice Hall,

Schreiber, J. B., Nora, A., Stage, F. K., Barlow, E. A., \& King, J. (2006). Reporting structural equation modeling and confirmatory factor analysis results: A review. The Journal of educational research, 99(6), 323-338. https://doi.org/10.3200/JOER.99.6.323-338

Schroder, H. M. (1989). Managerial competence: The key to excellence. Kendall/Hunt Publishing Company.

Somech, A., \& Drach-Zahavy, A. (2004). Exploring organizational citizenship behaviour from an organizational perspective: The relationship between organizational learning and organizational citizenship behaviour. Journal of occupational and organizational psychology, 77(3), 281-298. https://doi.org/10.1348/0963179041752709

Ton, Z., \& Huckman, R. S. (2008). Managing the impact of employee turnover on performance: The role of process conformance. Organization Science, 19(1), 56-68. https://doi.org/10.1287/orsc.1070.0294

Trougakos, J. P., Beal, D. J., Cheng, B. H., Hideg, I., \& Zweig, D. (2015). Too drained to help: A resource depletion perspective on daily interpersonal citizenship behaviors. Journal of Applied Psychology, 100(1), 227. https://doi.org/10.1037/a0038082

Verma, N., Rangnekar, S., \& Barua, M. K. (2012). Team effectiveness in Indian organizations. Delhi Business Review, 13(2), 43-54.

Williams, S., Pitre, R., \& Zainuba, M. (2002). Justice and organizational citizenship behavior intentions: Fair rewards versus fair treatment. The journal of social psychology, 142(1), 33-44. https://doi.org/10.1080/00224540209603883

\section{Copyright Disclaimer}

Copyright for this article is retained by the author(s), with first publication rights granted to the journal.

This is an open-access article distributed under the terms and conditions of the Creative Commons Attribution license (http://creativecommons.org/licenses/by/4.0/). 